\title{
THE ROLE OF IRRIGATION IN RIVER VALLEYS TO DEVELOP WATER QUALITY, PRODUCTION OF BIOMASS AND SUSTAINABLE RURAL DEVELOPMENT - CASE STUDY
}

Józef MOSIEJ, Faculty of Civil and Environmental Engineering, Warsaw University of Life Sciences-SGGW, PL 02-787 Warszawa, Nowoursynowska st. 166, Poland, jozef_mosiej@sggw.pl (corresponding author)

Teresa SUCHECKA, Faculty of Civil and Environmental Engineering, Warsaw University of Life Sciences-SGGW, PL 02-787 Warszawa, Nowoursynowska st. 166, Poland, teresa_suchecka@sggw.pl

\begin{abstract}
Ner river and its valley for over 170 years has been receiver for sewages from the city of Łódź. The natural system of this region (on the border of the watershed location, limitations of water supplies sources, lack of bigger natural rivers) in connection to city growth, lead to forming of specific system involving an agglomeration and water supplies system as well as wastewaters utilization system. The Ner river valley has the great potential to be effective in production biomass for energy purposes. Irrigation with polluted Ner river water cover fast growing plants high water and nutritional requirements. This would also work for the improvement of Ner river water quality. The achievement of good quality of water is not possible without irrigation of agricultural land in river valley. An amount of sewage discharged to Ner $\left(193,017 \mathrm{~m}^{3}\right.$ per day) several times higher then its natural flow in river. This is a result of strategy of water supply that is supported by transfer of water from Pilica river and underground water uptake for agglomeration. Relatively high runoff coefficient in years $1952-2011$ was equal to 0.325 for Ner, in comparison to 0.17 for other rivers in Warta watershed. Despite the low natural flow Ner river discharges annually relatively high contaminants' load to Warta river. In the analysed period (1995-2003) the annual average flow of Ner river amounted $10 \%$ of annual average Warta river flow below its estuary. The share of analysed indicators of contaminants' load approximated $27 \%$ for total nitrogen, $37 \%$ for phosphorus, $39 \%$ for BOD 5 and $28 \%$ for suspended solids. In the period 2004-2011 the annual average flow of Ner river amounted $13.8 \%$ of annual average Warta river flow. The share of investigated pollutants loads consists $27.9 \%$ for total nitrogen, $42.6 \%$ for phosphorus, $19.8 \%$ for BOD5 and $19.6 \%$ for suspended solids.
\end{abstract}

Keywords: water quality, load of pollutants, sewage, waste water treatment, biomass, Baltic Sea, HELCOM.

\section{INTRODUCTION}

The subject of the paper is related to a very current issue from the beginning of the 21 st century and activities aimed at increasing the efficiency of using natural resources by recycling mineral compounds contained in different waste products (by products), including municipal wastes water generated and discharged from large urban agglomerations.

Wastewater use in agriculture is much more commonplace than many believe. Currently, about 20 million hectares (7\% of total irrigated areas) of arable land around the world are irrigated untreated or partially treated waste water. Over $200 \mathrm{mln}$ farmers use treated waste water for irrigation. Wastewater use in agriculture has certain benefits, providing water and nutrients for the cultivation of crops, ensuring food supply to cities and reducing the pressure on available fresh water resources. However, wastewater is also a source of pollution, and can affect the health of users, consumers and the environment if safe practices are not applied. While populations and urban areas are growing at unprecedented rates and water scarcity is increasing, it is expected that, in the near future, the use of wastewater in agriculture will increase further in areas where fresh water is scarce (Ryden and Mosiej, 2000; Mateo-Sagasta et al. 2013; Hussain I., et al., 2002; Mustafayev and Umirsakov, 2013).

One of the main environmental problems in countries lying on the Baltic Sea is the limitation of phosphorus inflow from both point sources as well as dispersed sources. Experts in the field of hydrochemistry estimate that at the beginning of the 21st century (in 2000) the load of biogenic compounds discharged into the Baltic Sea was respectively about 814 thousand $\mathrm{Mg}$ of nitrogen and 42 thousand $\mathrm{Mg}$ of phosphorous per year. However, at the beginning of the 20th century (in 1900) the load was $100,000 \mathrm{Mg}$ and 10,000 Mg. Critical values are, respectively, 650,000 Mg and 32,000 Mg. According to the HELCOM regulations, by 2021 countries lying on the Baltic Sea should reduce the loads of nutrients by 15 thousand $\mathrm{Mg}$ of phosphorus to the level of 28.3 thousand $\mathrm{Mg}$ and nitrogen by 133 thousand $\mathrm{Mg}$ to the level of 550 thousand $\mathrm{Mg}$. Poland's share in the reduction should amount to $58.3 \%$ (8.75 thousand $\mathrm{Mg}$ ) in the case of phosphorus and $46.9 \%(62.4$

Copyright (C) 2017 The Authors. Published by Aleksandras Stulginskis University. This is an open-access article distributed under the terms of the Creative Commons Attribution License (CC-BY 4.0), which permits unrestricted use, distribution, and reproduction in any medium, provided the original author and source are credited. 
thousand $\mathrm{Mg}$ ) in the case of nitrogen reduction Poland should reduce the phosphorus load by $58.3 \%$ ( 8.75 thousand $\mathrm{Mg}$ ) and nitrogen by $46.9 \%$ (62.4 thousand $\mathrm{Mg}$ ). One of the ways of limiting discharges of biogenic compounds may be the use of municipal wastewater after purification by WWTP for irrigation of agricultural areas for both feed production and biomass production for energy purposes. In Poland about 40000 ha is irrigated use mostly industrial waste water (Mosiej 2011, Mosiej and Bus, 2015).

\section{RESEARCH OBJECT AND METHODS}

The paper presents an example of agricultural use of sewage in the scale of a fairly large facility with an area of approximately 3300 ha currently and in the past with an area of 4500 ha. The system removed every year about $750 \mathrm{Mg}$ of phosphorus and $2300 \mathrm{Mg}$ of nitrogen. Currently, the system is still in operation and the estimated reduction in phosphorus is about $200 \mathrm{Mg}$ of phosphorus and about $1500 \mathrm{Mg}$ of nitrogen. The Ner river basin with marked sampling points is shown in Fig. 1 (Komorowski et all., 2005; Mosiej 1999; Karczmarczyk and Mosiej, 2005, 2007; Mosiej and Multan, 1998; Somorowski et all., 1991).

The changes in the ecological state of the Ner River and its valleys in the 1995-2011 survey were dependent on strong anthropopression associated with the Łódź agglomeration industry. In the upper part of the Ner River and tributaries water quality, they were subjected to long-term degradation by the discharge of both municipal and industrial pollutants. Sewage water until 1995 were mechanically cleaned and full operation of the biological cleaning line in WWTP took place only in the years 2004-2009 (Penczak et al., 2010).

At the same time, due to the fall of many industrial factories mostly related to cotton processing for the clothing industry (such as yarns, dye works) that produced highly polluted industrial wastewater, the amount of waste water as well as their chemical composition changed. In 1989, the amount of sewage flowing into the treatment plant amounted to 139575 thousand $\mathrm{m}^{3} /$ year and in the years 2011-69 720 thousand $\mathrm{m}^{3} /$ year with an average annual inflow in the years 2004-2011 amounting to $197289 \mathrm{~m}^{3} /$ day. The total reduction of nitrogen and phosphorus in the plant in 2004-2011 amounted to $77 \%$ and $87 \%$ respectively, while maintaining the concentrations of these nutrients in treated sewage in accordance with applicable regulations. According to the data, the share of nitrogen and phosphorus loads from wastewater treatment plants in the load of the Ner river pollutants dropped significantly in 2004-2011 (Mosiej et all. 2007 a,b).
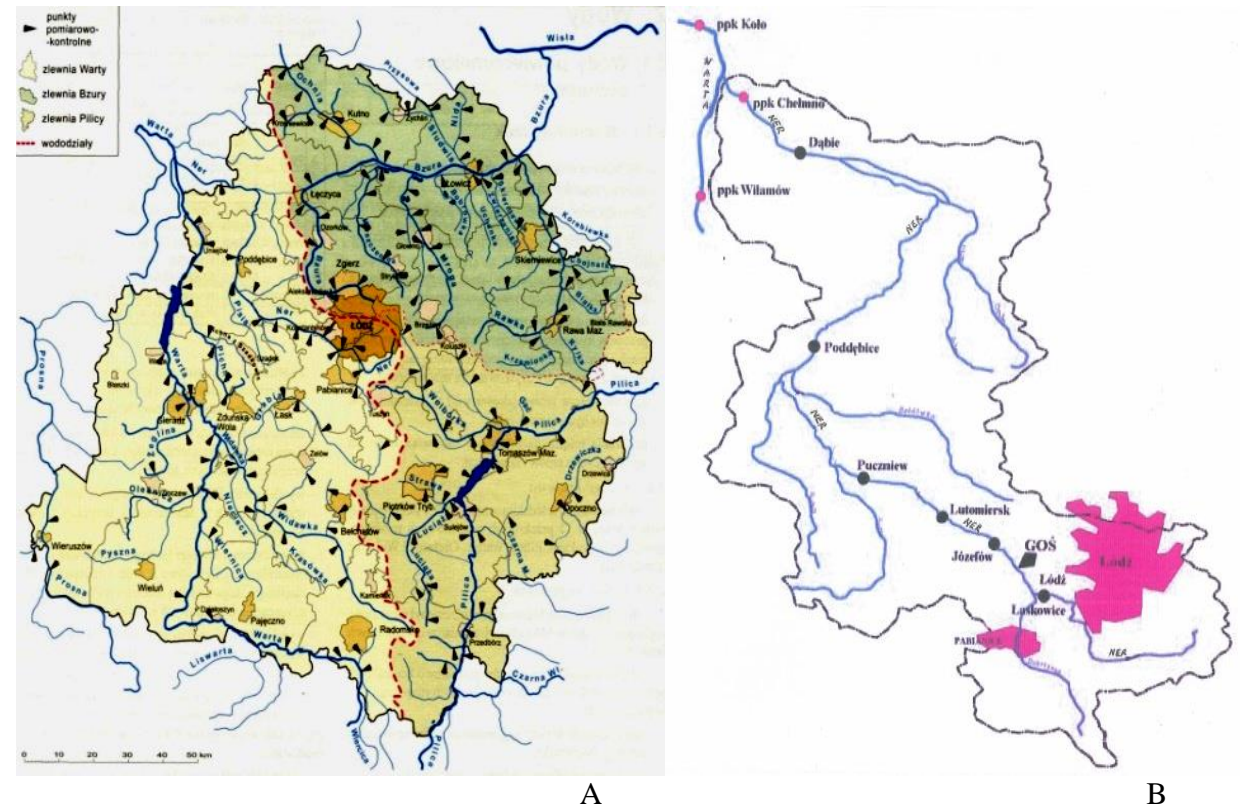

Figure 1. Map of the Warta river catchment with Ner tributary (A) and detail map of Ner river (B) catchment with sampling point (GOS-WWTP in Łódź)

\section{RESULTS}

In Table 1 shows the changes in the load of the basic pollutants in the two comparative study periods (1999-2003) and (2004-2011) at the outflow from the treatment plant. The data indicate a 10-fold decrease in BOD 5 , over 2-fold decrease in $\mathrm{N}_{\text {tot }}$, 4-fold decrease in $\mathrm{P}_{\text {tot }}$, and a nearly 6-fold decrease in suspension solid. For the Chełmno cross-section on the Ner river, this drop was respectively: for $\mathrm{BOD}_{5}-3$-fold, $\mathrm{N}_{\text {tot }}{ }^{-2}$-fold, $\mathrm{P}_{\mathrm{og}}$. approx. 3 times and suspensions solids about 2.5 times. It can be seen that the improvement of the quality of water discharged from the treatment plant does not translate directly into the quality of Ner water at the Warta estuary. The share of the pollutant load coming from the treatment plant in the total value of the load for the Chełmno cross-section in the years 2004-2011 was: for BZT $-43 \%$, $\mathrm{N}_{\text {tot. }}-64 \%, \mathrm{P}_{\mathrm{og}} .57 \%$, suspended solids $37 \%$. 
Table 1. A comparison of average yearly loads in outflow from the WWTP in Łódź and in the Chełmno cross section of the Ner river between 1999-2003 and 2004-2011.

\begin{tabular}{|l|l|l|l|l|}
\hline \multicolumn{2}{|l|}{} & Load Mg/year WWTP Łódź 99.7 km & \multicolumn{2}{l|}{ Load Mg/year Ner (Chełmno 5 km) } \\
\hline & $\begin{array}{l}\text { Average per year in period } \\
1999-2003\end{array}$ & $\begin{array}{l}\text { Average per year in period } \\
2004-2011\end{array}$ & $\begin{array}{l}\text { Average per year } \\
\text { in period } \\
1999-2003\end{array}$ & $\begin{array}{l}\text { Average per year } \\
\text { in period } \\
2004-2011\end{array}$ \\
\hline Indicator of pollution & 5503 & 582 & 4196 & 1339 \\
\hline $\mathrm{N}_{\text {tot }}$ & 2506 & 1132 & 3237 & 1773 \\
\hline $\mathrm{P}_{\text {tot }}$ & 274 & 68 & 332 & 119 \\
\hline Suspended sollids & 6549 & 1115 & 6939 & 3014 \\
\hline
\end{tabular}

Table 2. Comparison of average annual loads for three sections: Ner (Chełmno), Warta (Wilamów - Uniejów), Warta (Koło), 1995 2003 and 2004-2011.

\begin{tabular}{|c|c|c|c|c|c|c|}
\hline \multirow[b]{2}{*}{$\begin{array}{l}\text { Indicator } \quad \text { of } \\
\text { pollution }\end{array}$} & \multicolumn{2}{|l|}{$\begin{array}{l}\text { Load Mg/year } \\
\text { (Chełmno } 5 \mathrm{~km})\end{array}$} & \multicolumn{2}{|c|}{$\begin{array}{l}\text { Load Mg/year } \\
\text { Warta (Wilamów,Uniejów) }\end{array}$} & \multicolumn{2}{|l|}{$\begin{array}{l}\text { Load Mg/year } \\
\text { Warta ( Koło) }\end{array}$} \\
\hline & $\begin{array}{l}\text { Average per year } \\
\text { in period } \\
1995-2003 \\
\end{array}$ & $\begin{array}{l}\text { Average per year } \\
\text { in period } \\
2004-2011\end{array}$ & $\begin{array}{l}\text { Average per year } \\
\text { in period } \\
1995-2003\end{array}$ & $\begin{array}{ll}\text { Average per } \\
\text { year in } \\
\text { period } \\
2004-2011 \\
\end{array}$ & $\begin{array}{l}\text { Average per } \\
\text { year in period } \\
1995-2003\end{array}$ & $\begin{array}{l}\text { Average per } \\
\text { year } \\
\text { in period } \\
2004-2011 \\
\end{array}$ \\
\hline BOD5 & 6337 & 1339 & 6181 & 3198 & 16071 & 6762 \\
\hline $\mathrm{N}_{\text {tot }}$ & 3380 & 1773 & 4672 & 4229 & 12508 & 6350 \\
\hline $\mathrm{P}_{\text {tot }}$ & 439 & 119 & 295 & 183 & 1177 & 279 \\
\hline Suspended sollids & 9908 & 3014 & 19557 & 8139 & 35197 & 15354 \\
\hline
\end{tabular}

Despite such a significant improvement in the quality of waters discharged from the treatment plant, the proportion of pollutant load remains high and results from the small river flows in relation to the outflows from the treatment plant. The concentration of nitrogen and phosphorus compounds in the river sections before and after the outflow of purified sewage Tab. 3 indicate a lower content of biogenic and organic compounds in the upper course, which not covered by pollutant emissions from WWTP in Łódź (Fig. 2,3,4).

Table.3. Concentrations of selected forms nitrogen $\left(\mathrm{N}_{\text {tot }}\right.$ and N-NO 3$)$ and phosphorus $\left(\mathrm{P}_{\text {tot }}\right.$ and $\left.\mathrm{PO}_{4}\right)$ in Ner river in 4 cross-sections in $\mathrm{mg} / \mathrm{dm}^{3}$

\begin{tabular}{|c|c|c|c|c|c|c|c|c|c|c|c|c|c|c|c|c|}
\hline \multirow[b]{2}{*}{ Year } & \multicolumn{4}{|c|}{ Smulsko (101.5 km) } & \multicolumn{4}{|c|}{$\begin{array}{l}\text { Ner }(99.7 \mathrm{~km}) \text { outflow from } \\
\text { WWTP in Łódź }\end{array}$} & \multicolumn{4}{|c|}{ Lutomiersk $(88.8 \mathrm{~km})$} & \multicolumn{4}{|c|}{ Dąbie $(12,8 \mathrm{~km})$} \\
\hline & $\begin{array}{l}\mathrm{mg} / \\
\mathrm{dm}^{3} \\
\mathrm{~N}_{\text {tot }}\end{array}$ & $\begin{array}{l}\mathrm{mg} / \\
\mathrm{dm}^{3} \mathrm{~N} \\
\left(\mathrm{NO}_{3}\right)\end{array}$ & $\begin{array}{l}\mathrm{mg} / \\
\mathrm{dm}^{3} \\
\mathrm{P}_{\text {tot }}\end{array}$ & $\begin{array}{l}\mathrm{mg} / \\
\mathrm{dm}^{3} \\
\mathrm{PO}_{4}\end{array}$ & $\begin{array}{l}\mathrm{mg} / \\
\mathrm{dm}^{3} \\
\mathrm{~N}_{\text {tot }}\end{array}$ & \begin{tabular}{|l|}
$\mathrm{mg} /$ \\
$\mathrm{dm}^{3} \mathrm{~N}$ \\
$\left(\mathrm{NO}_{3}\right)$ \\
\end{tabular} & $\begin{array}{l}\mathrm{mg} / \\
\mathrm{dm}^{3} \\
\mathrm{P}_{\text {tot }} \\
\end{array}$ & $\begin{array}{l}\mathrm{mg} / \\
\mathrm{dm}^{3} \\
\mathrm{PO}_{4} \\
\end{array}$ & $\begin{array}{l}\mathrm{mg} / \\
\mathrm{dm}^{3} \\
\mathrm{~N}_{\text {tot }} \\
\end{array}$ & $\begin{array}{l}\mathrm{mg} / \\
\mathrm{dm}^{3} \mathrm{~N} \\
\left(\mathrm{NO}_{3}\right)\end{array}$ & $\begin{array}{l}\mathrm{mg} / \\
\mathrm{dm}^{3} \\
\mathrm{P}_{\text {tot }} \\
\end{array}$ & $\begin{array}{l}\mathrm{mg} / \\
\mathrm{dm}^{3} \\
\mathrm{PO}_{4}\end{array}$ & $\begin{array}{l}\mathrm{mg} / \\
\mathrm{dm}^{3} \\
\mathrm{~N}_{\text {tot }}\end{array}$ & $\begin{array}{l}\mathrm{mg} / \\
\mathrm{dm}^{3} \mathrm{~N} \\
\left(\mathrm{NO}_{3}\right)\end{array}$ & $\begin{array}{l}\mathrm{mg} / \\
\mathrm{dm}^{3} \\
\mathrm{P}_{\text {tot }} \\
\end{array}$ & $\begin{array}{l}\mathrm{mg} / \\
\mathrm{dm}^{3} \\
\mathrm{PO}_{4}\end{array}$ \\
\hline 2004 & 5.46 & 1.96 & 0.29 & 0.27 & 30.7 & 9.26 & 2.27 & 1.2 & 24 & 5.6 & 2.52 & 2.69 & 11.6 & 5.22 & 0.64 & 0.93 \\
\hline 2005 & 6.22 & 2.38 & 0.31 & 0.33 & 24.7 & 14.8 & 1.1 & 0.52 & 27.7 & 9.02 & 2.14 & 1.57 & 10.42 & 6.14 & 0.43 & 0.7 \\
\hline 2006 & 5.78 & 2.26 & 0.32 & 0.31 & 33.7 & 5.96 & 1.74 & 1.86 & 25.3 & 3.19 & 1.67 & 2.46 & 11.05 & 4.58 & 0.56 & 0.96 \\
\hline 2007 & 5.99 & 2.45 & 0.36 & 0.26 & 14.8 & 6.61 & 0.8 & 1.21 & 12.8 & 4.74 & 1.22 & 2.31 & 8.39 & 4.5 & 0.62 & 1.05 \\
\hline 2008 & 6.2 & 2.31 & 0.29 & 0.3 & 12.1 & 5.83 & 0.53 & 0.68 & 12.06 & 6.43 & 0.79 & 1.49 & nd & nd & nd & nd \\
\hline 2009 & 5.61 & 2.45 & 0.27 & 0.28 & 17.1 & 4.63 & 0.72 & 1.2 & 12.8 & 5.43 & 0.61 & 0.64 & nd & nd & nd & nd \\
\hline
\end{tabular}

The balance above indicates that on average about half of the value of individual indicators comes from other sources outside the WWTP in Lodz. As of 2012 the volume of water in $\mathrm{m}^{3} /$ year discharged from the remaining treatment plants to the Ner River accounted for about $10 \%$ of the volume of water discharged from the WWTP in Lodz.

The analysis of bottom sediments in four sections (Puczniew, Lutomiersk, Poddębice, Dąbie) made in 2013 showed concentrations of $\mathrm{N}_{\text {tot }}$ from $23-50 \mathrm{mg} / \mathrm{dm}^{3}$ and $P_{\text {tot }}$ from $4.5-5.7 \mathrm{mg} / \mathrm{dm}^{3}$. The potential source of the remainder of the load is the emission from the bottom sediment, which is further activated by the damming constructions. A significant part of organic compounds has been deposited in the years of poor functioning of the treatment plant and their slow mineralization associated with the self-cleaning of the river may still result in an increase in the content of biogenic compounds in the river's waters for many years (Mosiej et al.2007).

The increasing potential of self-cleaning of the river can be determined by analyzing the values of $\mathrm{BOD}_{5}$ indicators in 2004-2009 in the sections of Lutomiersk - Poddębice - Chełmno, which show that as the distance from the source drops away, the values decrease along the river. This downward trend is equally pronounced over time (Fig.3). For comparison, BOD 5 values in the Smulsko section, before departure from the WWTP in 2004-2010, remain at a stable level. Unfortunately, in our concentration analysis, the fluctuations of Ner flows associated with rainfall were not taken into account.

Interesting conclusions are drawn by the analysis of total phosphorus and phosphorus concentrations in four selected cross-sections in 2004-2009. For Smulsko section (before the outlet of the WWTP-GOS) $\mathrm{PO}_{4}$ in part $\mathrm{P}_{\text {tot }}$ is at a similar level. In the section of Ner at the outlet from the WWTP the participation of $\mathrm{PO}_{4}$ in $\mathrm{P}_{\mathrm{og}}$ has been increasing since 2006, similarly for the section of Lutomiersk. For the Dąbie section (at the mouth of the Warta river) this trend is noticeable already in 2004. The increase in the share of phosphorus trophic forms in the general phosphorus was influenced by the modernization of the treatment plant (full biological decomposition of phosphorus organic compounds), 
but above all stimulation of self-purification processes in the river, which proceed faster and farther away from pollutant emissions (Fig 2. 3. 4). Only a significant reduction of organic compounds entering the river, expressed in $\mathrm{BOD}_{5}$ and COD indicators, indicates the natural self-cleaning potential of the sewage receiver leaving Łódź.

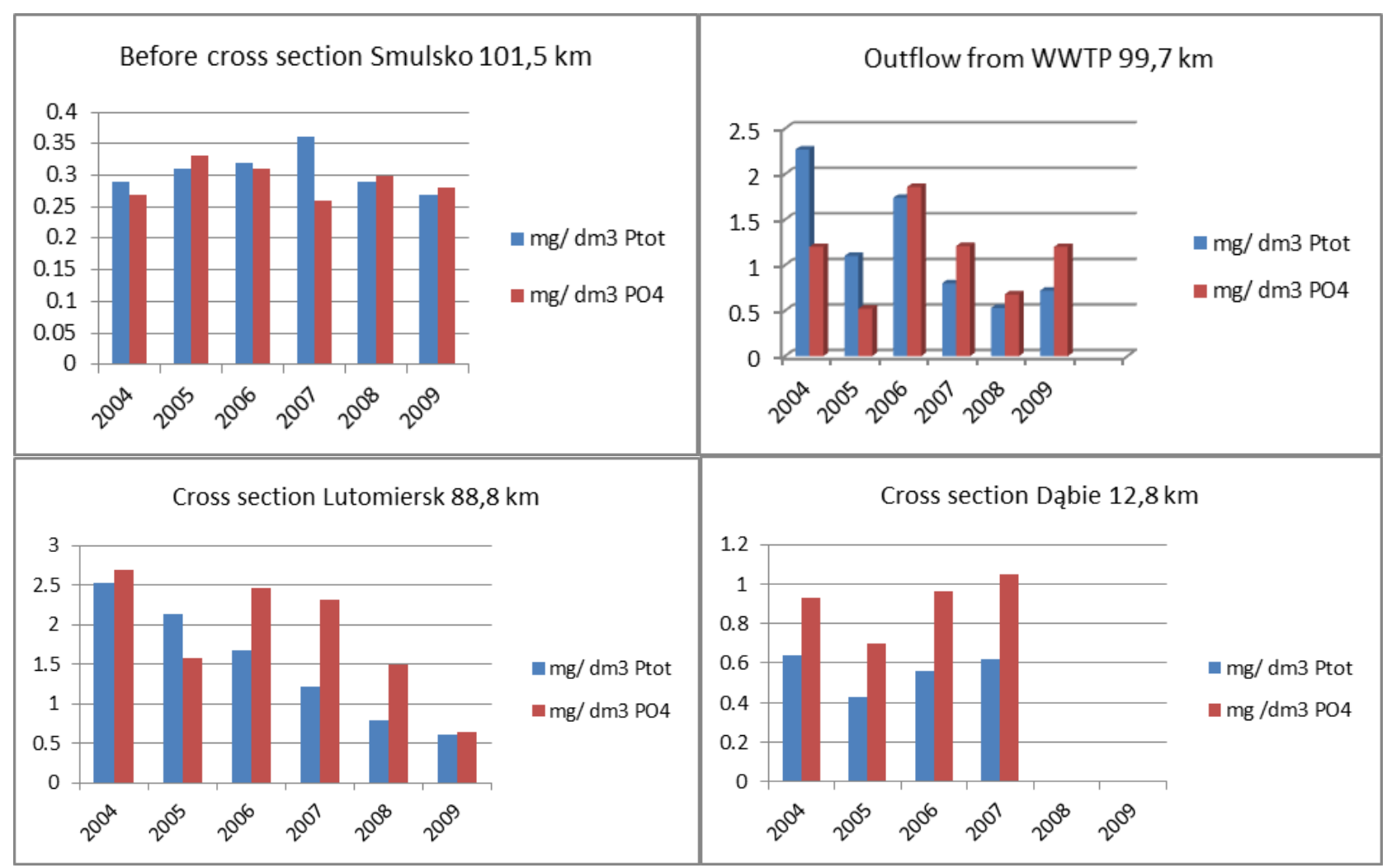

Figure 2. Changes of concentration of $\mathrm{P}_{\text {tot }}$ and $\mathrm{PO}_{4}$ in 4 cross sections (average per year)

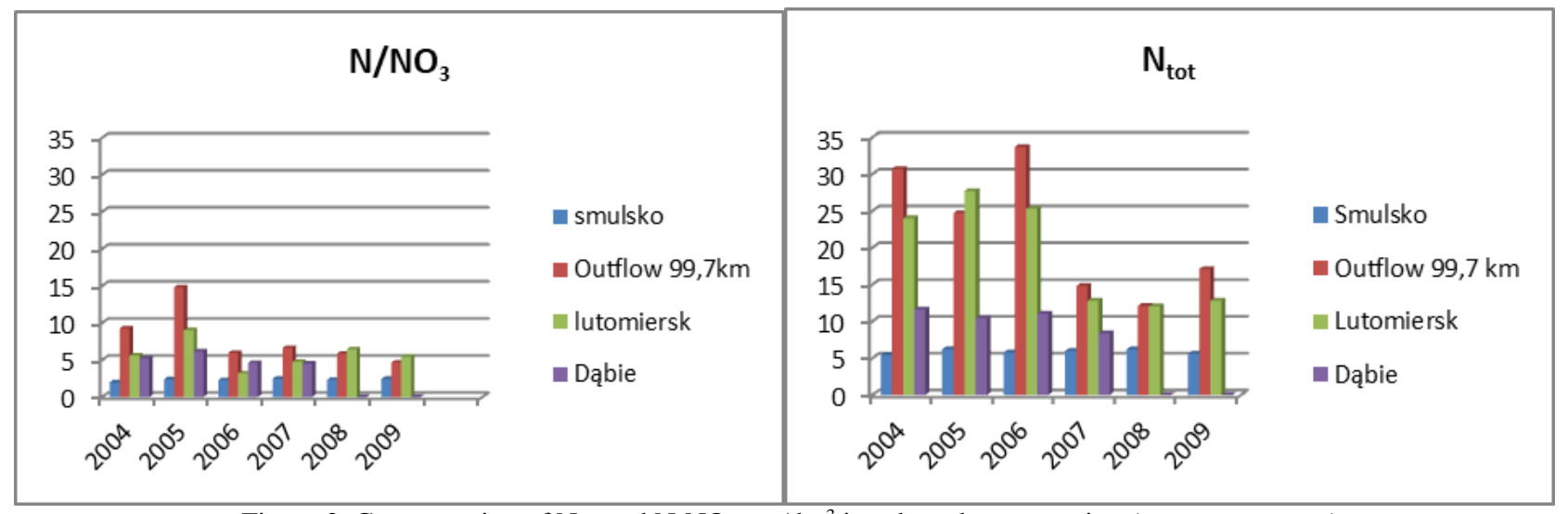

Figure 3. Concentration of $\mathrm{N}_{\mathrm{tot}}$ and $\mathrm{N}-\mathrm{NO}_{3} \mathrm{mg} / \mathrm{dm}^{3}$ in selected cross section (average per year)

Data on total nitrogen concentrations indicate a decrease in the cross-sections of Lutomiersk and Dąbie in 2007 (Fig. 2). At the same time. the $\mathrm{N}_{\text {tot }}$ concentration decreases in the Ner section at the WWTP in outlet. hence it can be correlated with the improvement of the quality of discharged wastewater. The share of nitrate concentrations $\left(\mathrm{NO}_{3}\right)$ in $\mathrm{N}_{\text {tot }}$ remains on average at $50 \%$ (Fig.2).

The intensity of river self-purification processes can also be noticed by comparing the $\mathrm{BOD}_{5}$ load values in 1995 -2003 and 2004-2011 (Table 2) for the Chełmno section. Its value in the years 2004-2011 represents only $20 \%$ of the value of the comparative period and is the smallest for selected indicators of pollution (Fig. 3).

It seems significant that the share of loads of selected pollutants carried out with the Ner waters to the Warta river in the years 2004-2011 decreased several times in comparison with the 1995-2003 multi-annual period (Table 2). In the second period. $\mathrm{BOD}_{5}$ accounted for only $21 \% . \mathrm{N}_{\text {tot }}-52 \% . \mathrm{P}_{\text {tot }}-27 \%$ and a total suspension of $30 \%$. As can be seen from the Table 2 the values of these indices have also decreased for the section of Koło and Uniejów on the Warta River (Fig. 1). 


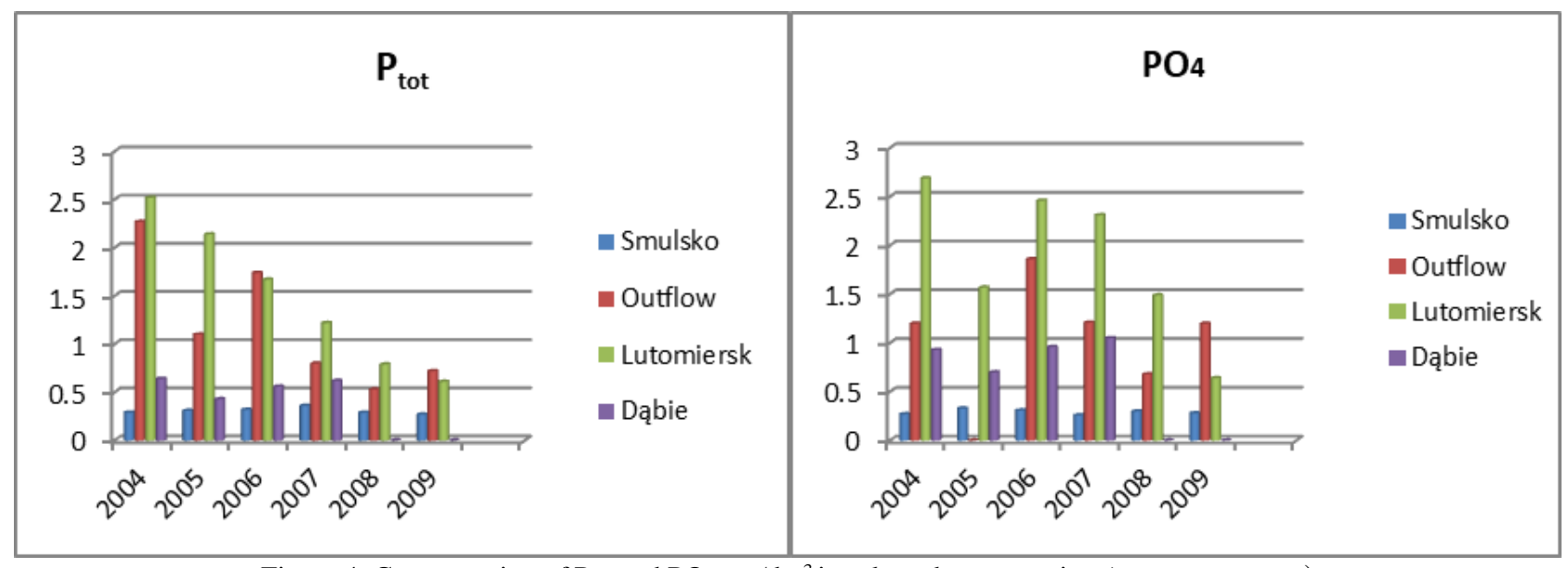

Figure 4. Concentration of $\mathrm{P}_{\text {tot }}$ and $\mathrm{PO}_{4} \mathrm{mg} / \mathrm{dm}^{3}$ in selected cross section (average per year)

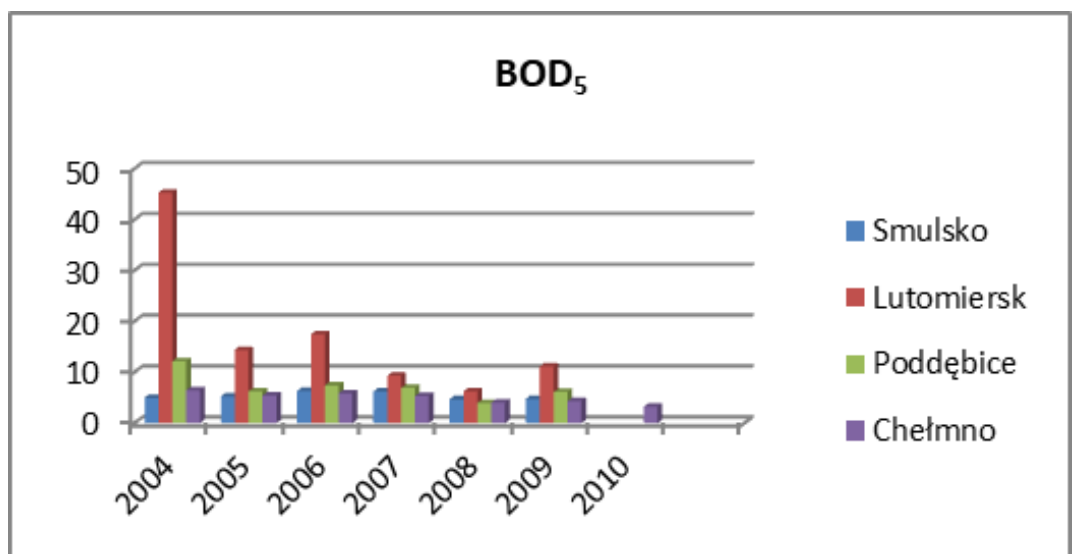

Figure 5. Value of $\mathrm{BOD}_{5}\left(\mathrm{mg} \mathrm{O}_{2} / \mathrm{dm}^{3}\right)$ indicator in selected cross section (average per year)

\section{CONCLUSIONS}

In the last 20 years, water storage devices in the Ner River, which were intended and used early only for irrigation after appropriate reconstitution, are also used for the production of electric energy. Currently, 11 out of 17 weirs work as hydroelectric plants, contributing to the development of hydropower, increasing water retention in the valley and production of green energy, which is in line with the principles of sustainable development of rural areas. This means that the river and valley are not only a place for sewage treatment but also a place for the production of biomass (used as animal feed or for energy purposes) and for the production of electricity in hydropower plants. This is an example of multifunctional and sustainable use of rural areas in the early 21 st century (Lik and Soltuniak 2012).

A significant impact on the water quality in the Ner River and the condition of the environment in the valley were irrigated by adjacent grasslands, covering both the deficiencies of moisture in the soil and fertilizing needs. It is estimated that on the irrigated area in the years 1980-1995, approximately 4500 ha were used for irrigation during vegetation period in the wet year of $13 \%$. and in the dry year $34 \%$ of sewage flowing out of Łódź. Application of wastewater during the vegetation period promoted uptake of nutrients by biomass, resulting in a production of $11-13 \mathrm{Mg}$ per hectare per year.

As can be seen from Table 2, the values of these indicators also dropped for the section of Koło and Uniejowa on the Warta River (Fig.1). When irrigating meadows in the river valley, over 1,300 Mg of nitrogen and about $200 \mathrm{Mg}$ of phosphorus will be removed from the Ner river with an annual biomass production of $60,000 \mathrm{Mg}$.

At the same time, on the one hand, this will improve the quality of water in the river, and on the other - the accumulation of sediments in the riverbed and the valley.The result of these activities was the creation of light valley sands watered with sewage, anthropogenic soils with high organic matter content (up to $5 \%$ in the $0-20 \mathrm{~cm}$ layer) with the possibility of toxic substances accumulation.

Currently in the Ner valley there are 17 weirs accumulating water used, among others, for irrigation, which covers about 3300 ha of grassland. It should be noted that, on the one hand, hydro technical devices such as weirs, canals, drainage ditches and other irrigation devices stop large quantities of suspensions, which are subject to local deposition and on the other hand contribute to water aeration, which in the long run stimulates river self-cleaning processes.

Currently, about 3300 hectares are irrigated, which contributes to the reduction of nitrogen and phosphorus content in the Ner River. Assuming that the system keeps about $200 \mathrm{Mg}$ of phosphorus and $1500 \mathrm{Mg}$ of nitrogen in biomass and in the soil annually. The ecological effect of irrigation in Ner river valley in the Dąbie section at the average water flow $9.22 \mathrm{~m}^{3} / \mathrm{s}$ is the reduction of nitrogen concentration by $5 \mathrm{~g} / \mathrm{m}^{3}$ and phosphorus by $0.72 \mathrm{~g} / \mathrm{m}^{3}$. Of course, the additional effect is the aeration of water as a result of flow through the damming devices and the uptake of biogenic compounds by 
aquatic vegetation and the deposition of biogenic compounds in irrigation channels and ditches.

\section{REFERENCES}

1. Hussain, I., Raschid, L., Hanjra, M. A, Marikar, F., Van der Hoek, W., 2002. Wastewater use in agriculture: Review of impacts and methodological issues in valuing impacts. Working Paper 37. Colombo. Sri Lanka: International Water Management Institute.

2. Jaskuła, J., Wicher-Dysarz, J., Sojka, M., Dysarz, T., 2016. Ocena zmian zawartości związków biogennych w wodach rzeki Ner. Inżynieria Ekologiczna, Vol. 46, pp. 31-37. [In Polish] https://doi.org/10.12912/23920629/61448

3. Karczmarczyk, A., Mosiej. J., 2005. Wastewater treatment combine with nutrients reuse. Ann. Warsaw Agricult.Univ. - SGGW. Land Reclam, 36. pp. 89-98.

4. Karczmarczyk A. Mosiej J, 2007: Aspects of wastewater treatment on short rotation plantations (SRP) in Poland. Journal of Environmental Engineering and Landscape Management. Volume 15, Issue 3.

5. Komorowski H, Karczmarczyk A., Mosiej J., 2005: The role of the Wastewater Irrigation and Sludge Utilization in Sustainable Rural Development-Case study from Lodz Region. In:ICID 21European Regional Conference.182-187.|

6. Lik, J., Sołtuniak, J., 2012. Wykorzystanie zasobów wodnych woj. łódzkiego na cele energetyki i towarzszącej jej turystyki. Centrum Badań i Innowacji Pro.Akademia, Oddział PAN w Łodzi. [In Polish]

7. Mateo-Sagasta, J., Medlicott, K., Qadir, M., Raschid-Sally, L., Drechsel, P., Liebe, J., 2013: Safe Use of Wastewater in Agriculture Proceedings series No 11. Published by UNW-DPC. Bonn. p.80.

8. Mosiej, J., 1999. Przyrodniczo - techniczne uwarunkowania gospodarowania wodą w dolinie rzeki Ner. Wyd. SGGW. Warszawa. [In Polish]

9. Mosiej, J., 2011. Rural water management as important factor of sustainable rural development in Poland - some aspects. Rural Development 2011, Vol.5, Book 2, pp. 326-331.

10. Mosiej, J., Bus, A., 2015. New challenges in rural water management in Poland - selected problems. Rural Development 2015, pp. 1-6. DOI: http://doi.org/10.15544/RD.2015.078

11. Mosiej, J., Karczmarczyk, A. 2001. Ecological Engineering for Ner River water quality improvement - possible solutions. Ann. Warsaw Agricult. Univ. - SGGW. Land Reclam. 31. 75-86.

12. Mosiej, J., Komorowski, H., Karczmarczyk, A., Suska, A., 2007a. Wpływ zanieczyszczeń odprowadzanych z aglomeracji łódzkiej na jakość wody w rzekach Ner i Warta. Acta Scientiarum Polonorum. Formatio Circumiectus, No. 6(2), pp.. 19-30. [In Polish]

13. Mosiej, J., Komorowski, H., Karczmarczyk, A., 2007b. Factors affecting water quality in degraded sewage receivers-case study of the phosphorus dynamics in the Ner River. Journal of Water and Land Development, Vol. 11, pp. 103-116. https://doi.org/10.2478/v10025-008-0009-y

14. Mosiej, J,. Multan., H. 1998. Grasslands as a natural filter for municipal waste water and biogens. In: Pertu, K.,Obarska-Pempkowiak, H. [Eds]. Sewage treatment by means of pine. willow. reed and grass vegetation filters. Agric. Univ. Uppsala. pp. 59-62.

15. Mustafayev, Zh.S., Umirsakov, S.I., 2013. Ecological safety technologies of sewage utilization in specific agroecosystems. (Ekologiceski bezopasnye tehnologii utilizacii stocnyh vod v specializirovannyh agrolandschaftah).Taras. 247 p. [In Russian].

16. Penczak, T., Kruk, A., Grabowska, J., Śliwińska, A., Koszaliński, H., Zięba, G., Tybulczyk, S., Galicka, W., Marszał, L., 2010. Wpływ stopniowej poprawy jakości wody w rzece Ner na regenerację ichtiofauny. Roczniki naukowe. PZW. 23. 97-117. [In Polish]

17. Ryden, L., Mosiej, J., 2000. Wetlands and Agricultural Runoff. In: Water Use and Management - Book 2, Sustainable Water Management, Baltic University Programme, Uppsala, pp. 129-140.

18. Somorowski, Cz. Multan, H., Mosiej, J., Szatyłowicz, J., 1991. Wpływ nawodnień ściekami na plonowanie i elementy bilansu wodnego gleby użytków zielonych w dolinie rzeki Ner. ZN AR Kraków, Vol. 249, pp. 81-101. [In Polish]

19. Wastewater treatment and use in agriculture. FAO Corporate Document Repository. http://www.fao.org/docrep/t0551e/t0551e03.htm\#TopOfPage 